\title{
Somatostatin receptor subtype expression in the human heart: differential expression by myocytes and fibroblasts
}

\author{
William H T Smith, R Unnikrishnan Nair ${ }^{1}$, Dawn Adamson ${ }^{2}$ \\ Mark T Kearney ${ }^{3}$, Stephen G Ball and Anthony J Balmforth \\ Integrated Molecular Cardiology Group, University of Leeds, Leeds LS2 9JT, UK \\ ${ }^{1}$ Department of Cardiothoracic Surgery, The General Infirmary at Leeds, Leeds LS1 3EX, UK \\ ${ }^{2}$ National Heart and Lung Institute, Imperial College, London SW3 6LY, UK \\ ${ }^{3}$ GKT School of Medicine, London WC2R 2LS, UK \\ (Requests for offprints should be addressed to A J Balmforth; Email: a.j.balmforth@leeds.ac.uk)
}

\begin{abstract}
In acromegaly, somatostatin receptor ligands (SRLs) can ameliorate left ventricular hypertrophy (LVH) and their use is associated with demonstrable improvements in various parameters of cardiac function. It remains unclear as to whether these beneficial effects are principally attributable to falling GH and IGF-I levels, or whether SRLs exert independent direct effects on the heart via somatostatin receptors. To help address this issue, we have sought to investigate somatostatin receptor expression in human heart. A human heart cDNA library was probed using PCR techniques to determine expression of somatostatin receptor subtypes. Subsequently, human heart biopsies and human cardiac fibroblasts and myocytes were analysed to determine whether expression differed between cardiac chambers or cell types. mRNAs for four of the five somatostatin receptor subtypes (sst1, sst2, sst4
\end{abstract}

and sst5) were shown to be co-expressed by the human heart. These receptors were present in both atrial and ventricular tissue. Human cardiac myocytes expressed mRNA for only sst1 and sst2, while human cardiac fibroblasts expressed all four subtypes found in whole heart tissue. The expression of functional somatostatin receptors on human cardiac fibroblasts was confirmed by mobilisation of intracellular calcium in response to somatostatin. The presence of cardiac somatostatin receptors raises the possibility of a direct effect of somatostatin analogues on the heart. Furthermore, the differential expression of somatostatin receptor subtypes by human cardiac myocytes and fibroblasts opens up the possibility of differential modulation of the cell types in the heart by subtype-specific somatostatin analogues.

Journal of Endocrinology (2005) 187, 379-386

\section{Introduction}

Acromegaly is a rare but important endocrine disorder associated with a reduced life expectancy. Subjects with uncontrolled acromegaly have a 2- to 5-fold greater mortality than controls, $60 \%$ of which is due to cardiovascular disease (Wright et al. 1970, Orme et al. 1998). The main structural cardiac abnormality is left ventricular hypertrophy (LVH) (for review see Colao et al. (2001a)). LVH in acromegaly is characterised by both myocyte hypertrophy and a disproportionate accumulation of fibrillar collagen (up to 8-fold greater than in biopsies from patients with mitral stenosis (Frustaci et al. 1999). Lymphomononuclear infiltration and areas of monocyte necrosis resembling myocarditis have also been described (Lie 1980). These changes are likely to account for the observed functional abnormalities of impaired left ventricular diastolic function, impaired exercise tolerance and ventricular arrhythmias which are recognised complications of cardiac involvement in acromegaly (Clayton 2003). The coexistence of hypertension increases the incidence of cardiac abnormalities (Colao et al. 2000a) and the risk of premature death (Holdaway et al. 2004).

Treatment with the somatostatin receptor ligands (SRLs) octreotide (Lim et al. 1992, Tokgozoglu et al. 1994, Colao et al. 2000b) and lanreotide (Baldelli et al. 1999, Manelli et al. 1999) has been shown to promote regression of $\mathrm{LVH}$ with some studies also demonstrating improvements in left ventricular diastolic function (Thuesen et al. 1989, Merola et al. 1993, Colao et al. 1999). It is worth noting, however, that while these results are encouraging, to date, no studies have been of sufficient duration to establish whether normalising cardiac structure ultimately translates into reduced cardiovascular mortality. In the meantime, therefore, we are dependent upon demonstrating improvements in surrogate markers of disease activity while the results of long-term follow-up studies are awaited. In this regard, treatment with SRLs is 
effective in suppressing various markers of acromegalic disease activity (Ezzat et al. 1992), which in turn has been associated with improved overall survival (Orme et al. 1998, Holdaway et al. 2004). Furthermore, improvements in exercise capacity (Padayatty et al. 1996) and cardiac output in subjects with heart failure (Chanson et al. 1990) have been reported following octreotide therapy. Together these data have led some authors to suggest that restoring cardiac structure and function should become an objective of treatment in acromegaly (Clayton 2003).

Up until now it has generally been assumed that LVH regression in response to SRL therapy is mediated through the reduction in circulating growth hormone $(\mathrm{GH})$ and insulin-like growth factor-I (IGF-I) levels (Colao et al. 2001b). To our knowledge, no studies have so far sought to determine whether there is a direct cardiac effect of SRLs in the reversal of acromegaly-associated cardiomyopathy and its consequences. Morover, if such an effect was present, it would mandate further studies to explore its potential relevance in patients with pathological LVH of other causes such as hypertension.

$\mathrm{LVH}$ is a frequent complication of hypertension with its presence well recognised as a marker for risk of death (Levy et al. 1994). Previously reported data suggest that regression of LVH associated with antihypertensive therapy is associated with improved outcome (Verdecchia et al. 1998, Mathew et al. 2001). The pathological changes in hypertensive LVH are similar to those found in acromegaly with disproportionate proliferation of cardiac fibroblasts and accumulation of fibrillar collagen. This growth of the cardiac interstitium has significant functional effects on the left ventricle leading to abnormal relaxation and the clinical syndrome of heart failure even before the development of systolic dysfunction (Weber \& Brilla 1991). Modulation of cardiac fibroblasts is therefore of particular interest in both acromegaly and hypertension. Several factors have been shown to contribute to the development of LVH in hypertension but particular interest has focused on IGF-I (for review see Delafontaine (1995)).

The peptide hormone somatostatin can inhibit both the release and mitogenic effects of growth factors including IGF-I. It exerts its effects through five G-protein-coupled receptor subtypes (sst1-sst5). These receptors couple to a variety of signal transduction pathways -including inhibition of adenylate cyclase (Patel et al. 1994), mobilisation of intracellular calcium (Akbar et al. 1994) and activation of protein tyrosine phosphatases (Buscail et al. 1995) - which can inhibit cell proliferation. In rat heart, sst1, sst3 and sst4 are expressed but sst 2 and sst 5 are not, as evidenced by mRNA expression (Bruno et al. 1993). In the human heart, mRNA encoding sst5 is present (O'Carroll et al. 1994). However, this study focused only on sst5 and did not look for the other receptor subtypes nor did it explore the location of sst5 expression within the heart. These two studies serve to highlight important species-specific differences in receptor subtype expression and emphasise the necessity
Table 1 PCR primers used in reactions to detect somatostatin receptor subtypes $\left(5^{\prime}-3^{\prime}\right)$

$\begin{array}{ll}\text { sst1 FP } & \text { CGCTGGCTGGTGGGCTTCGTGTTG } \\ \text { sst1 RP } & \text { CGCCGCCGGACTCCAGGTTCTCAG } \\ \text { sst2 FP } & \text { TCCAGGGTCCATTAAGGTGAGAA } \\ \text { sst2 RP } & \text { TAGGGAGCCCATTGCCAGTAGAC } \\ \text { sst3 FP } & \text { CGTGGTGGGCCTGCTGGGTAACTC } \\ \text { sst3 RP } & \text { GTGCGGCCGTGTAGATGATGAAGC } \\ \text { sst4 FP } & \text { GTGTGGCTGGCATCCCTGTTGGTC } \\ \text { sst4 RP } & \text { GATCGGCGGAAGTTGTCGGAGAGG } \\ \text { sst5 FP } & \text { TACATGCTGGGGCTGCCTTCCTG } \\ \text { sst5 RP } & \text { GCCCGCCGCCCTCACCTTCAC }\end{array}$

FP, forward primer; RP, reverse primer.

for studies in human tissue if meaningful conclusions with direct relevance to clinical practice are to be drawn.

In this study we have determined somatostatin receptor subtype expression at the mRNA level in the human heart. We have identified differential receptor subtype expression between myocytes and fibroblasts and demonstrate mobilisation of intracellular calcium in response to somatostatin in human cardiac fibroblasts.

\section{Materials and Methods}

\section{PCR analysis used to identify expression of human somatostatin receptor subtypes}

The primer pairs used for PCR analysis are shown in Table 1. Optimal PCR conditions for amplification of all five receptor subtypes were established using a QUICK Screen universal human cDNA library (Clontech) as a template. For sst1, sst3, sst 4 and sst5 receptors, a GC-2 cDNA PCR kit (Clontech) was used. Each $50 \mu \mathrm{l}$ reaction consisted of: $24 \mu \mathrm{l}$ ultrapure $\mathrm{H}_{2} \mathrm{O}, 10 \mu \mathrm{l} 5 \times$ buffer, $10 \mu \mathrm{l}$ GC Melt, $1 \mu \mathrm{l} 50 \times \mathrm{dNTP} \operatorname{mix}(10 \mathrm{mM}), 1 \mu \mathrm{l}$ forward primer $(25 \mu \mathrm{M}), 1 \mu \mathrm{l}$ reverse primer $(25 \mu \mathrm{M}), 1 \mu \mathrm{l}$ Advantage GC Polymerase Mix, $2 \mu$ l template cDNA. Cycle parameters used were: $94^{\circ} \mathrm{C}$ for $60 \mathrm{~s}$ (activation) followed by 35 cycles of $94{ }^{\circ} \mathrm{C}$ for $30 \mathrm{~s}$ (melting) and $68^{\circ} \mathrm{C}$ for $180 \mathrm{~s}$ (combined annealing extension). This was followed by a final extension period of $180 \mathrm{~s}$ at $68{ }^{\circ} \mathrm{C}$. For sst2 receptors, an Advantage PCR kit (Clontech) was used. Each $50 \mu \mathrm{l}$ reaction consisted of: $40 \mu \mathrm{l}$ ultrapure $\mathrm{H}_{2} 0,5 \mu \mathrm{l} 10 \times$ cDNA PCR buffer, $1 \mu \mathrm{l} 50 \times \mathrm{dNTP} \operatorname{mix}(10 \mathrm{mM}), 1 \mu \mathrm{l}$ forward primer $(25 \mu \mathrm{M}), 1 \mu \mathrm{l}$ reverse primer $(25 \mu \mathrm{M}), 1 \mu \mathrm{l}$ Advantage Polymerase Mix, $1 \mu$ template cDNA. Cycle parameters used were: $94^{\circ} \mathrm{C}$ for $60 \mathrm{~s}$ (activation) followed by 35 cycles of $94^{\circ} \mathrm{C}$ for $30 \mathrm{~s}$ (melting), $64{ }^{\circ} \mathrm{C}$ for $30 \mathrm{~s}$ (annealing) and $68^{\circ} \mathrm{C}$ for $150 \mathrm{~s}$ (extension). This was followed by a final extension period of $180 \mathrm{~s}$ at $68^{\circ} \mathrm{C}$. Appropriate negative PCR controls were used in every experiment. Products were initially identified by their size, 
determined using 1\% agarose gel electrophoresis, and subsequently confirmed by DNA sequencing of both strands. Once optimal PCR conditions were established, they were used to probe for expression of somatostatin receptor subtypes in a human heart cDNA library (Gibco) and cDNA prepared from heart biopsies, cardiac fibroblasts and cardiac myocytes.

\section{Human heart biopsies}

The investigation conforms with the principles outlined in the Declaration of Helsinki and received local research ethics committee approval. Biopsies of the right atrial appendage $(5 \mathrm{~mm} \times 5 \mathrm{~mm} \times 2 \mathrm{~mm})$ were taken using a scalpel at the time of right atrial cannulation for cardiopulmonary bypass in subjects undergoing mitral valve replacement or coronary artery bypass surgery. Endocardial biopsies $(2 \mathrm{~mm} \times 2 \mathrm{~mm} \times 1 \mathrm{~mm})$ of the left ventricle (LV) were taken from patients undergoing mitral valve replacement for lone mitral stenosis. None of the patients from whom an LV biopsy was taken had ischaemic heart disease and all had good left ventricular function at cardiac catheterisation and on echocardiography. All biopsies were snap-frozen immediately in liquid nitrogen and stored at $-70^{\circ} \mathrm{C}$, for mRNA extraction or placed in cell culture medium at $4{ }^{\circ} \mathrm{C}$ for fibroblast culture.

\section{$m R N A$ extraction and reverse transcription}

mRNA was extracted from both tissue and cultured cells using a $\mu$ MACs magnetic bead mRNA isolation kit (Miltenyi Biotec, Surrey, UK) according to the manufacturer's instructions. Briefly, cardiac tissue $(5-50 \mathrm{mg})$ was ground to a fine powder under liquid nitrogen and added to $1 \mathrm{ml}$ of lysis buffer. This was vortexed vigorously for 3 min and filtered before magnetic oligo-dT primer was added. The lysate was then run through a $\mu$ MACs column in a magnetic field. mRNA hybridised to the magnetic oligo-dT was held in the column while DNA, rRNA and proteins were removed using a series of wash steps. Thereafter mRNA was eluted in water. Myocyte and fibroblast cell pellets were resuspended in $1 \mathrm{ml}$ of lysis buffer and processed as above.

Reverse transcription was performed immediately after extraction of mRNA with a thermoscript reverse transcriptase PCR kit (Gibco) according to the manufacturer's instructions using an Oligo-dT primer. Appropriate negative controls were performed.

\section{Isolation of human cardiac fibroblasts and myocytes}

Human cardiac fibroblasts were isolated by a method similar to that of Neuss et al. (1996). Briefly, biopsies were washed and minced then incubated in Dulbeco's modified Eagle's medium (DMEM; Gibco) supplemented with antibiotic-antimycotic mix and $0 \cdot 1 \%$ BSA (Sigma) and $2000 \mathrm{u} / \mathrm{ml}$ collagenase (Worthington Biochemical Corporation, Lakewood, New Jersey, USA) at $37^{\circ} \mathrm{C}$ in $10 \%$ $\mathrm{CO}_{2}$ in air for $3 \mathrm{~h}$. Following this, the solution was centrifuged for $10 \mathrm{~min}$ at $220 \mathrm{~g}$ to produce a pellet of cardiac cells, which were then resuspended, washed and subsequently seeded into $75 \mathrm{~cm}^{2}$ flasks in growth medium consisting of DMEM supplemented with L-glutamine, antibiotic-antimycotic mix and 15\% foetal calf serum (Helena Biosciences, Sunderland, UK). Cells were incubated in $10 \% \mathrm{CO}_{2}$ at $37{ }^{\circ} \mathrm{C}$ for $30 \mathrm{~min}$. In these conditions only the fibroblast population adheres to the uncoated plastic. Thereafter, the culture medium was removed and $15 \mathrm{ml}$ fresh growth medium added. The adherent fibroblasts were allowed to grow in $10 \% \mathrm{CO}_{2}$ at $37^{\circ} \mathrm{C}$. When confluent, cells were trypsinised and seeded into larger flasks or multi-well plates. The rate of proliferation reduced markedly after the fifth to seventh passage as observed in earlier studies by Neuss et al. (1996) and, accordingly, all experiments were performed on cells between the first and fifth passage.

When cultured cells were used as a source of mRNA, they were trypsinised, resuspended in growth medium and then immediately centrifuged at $220 \mathrm{~g}$ for $5 \mathrm{~min}$ at $4{ }^{\circ} \mathrm{C}$ to form a pellet. The medium was removed and the cell pellet snap-frozen and stored at $-70{ }^{\circ} \mathrm{C}$ until mRNA isolation.

Cardiac myocytes were isolated from explanted, donor human hearts that were technically unsuitable for organ donation, using methods previously described (Davies et al. 1995). After isolation these cells were snap-frozen and stored at $-70{ }^{\circ} \mathrm{C}$ until mRNA isolation.

\section{Immunohistochemical characterisation of fibroblasts}

Cells were plated onto glass coverslips in 24-well plates and allowed to grow to around $40-70 \%$ confluency. The cells were fixed with $4 \%$ paraformaldehyde for $30 \mathrm{~min}$ at room temperature and then permeablised by washing $4 \times$ $15 \mathrm{~min}$ with $1 \% \mathrm{v} / \mathrm{v}$ TritonX in PBS. Cells were incubated overnight on a shaker at $4{ }^{\circ} \mathrm{C}$ with the following primary antibodies at 1:400 dilution:anti-vimentin (Sigma), anti $\alpha$-smooth muscle actin (Sigma) and anti-von Willebrands factor (Dako A/S Produktionsvej 42, DK-2600 Glostrup, Denmark). Following extensive washing, secondary fluorescent antibodies (donkey antimouse IgG conjugated to Cy3 for detection of antivimentin and anti $\alpha$-smooth muscle actin primaries and donkey anti-rabbit $\operatorname{IgG}$ conjugated to fluorescein isothiocyanate (FITC) for the anti-von Willebrands factor primary-Jackson ImmunoResearch Labs) were added at a dilution of 1:200 for $4 \mathrm{~h}$ at room temperature in the dark, with continuous agitation. Non-specifically bound secondary antibody was removed with three further 15 min washes with PBS. Cells were examined with an Axioskop epifluorescence microscope. Excitation light 
of $450-490 \mathrm{~nm}$ wavelength was used to visualise FITC and 534-558 nm wavelength to visualise Cy3, with BP515-565 and LP590 emission barrier filters respectively. Images were directly captured from the microscope with a JVC KY-F55BE colour charge-coupled device and an Acquis Video Imaging System.

\section{Measurement of intracellular calcium}

Cells grown on glass coverslips were incubated with the cell-permeant fluorescent probe fura 2-AM $(5 \mu \mathrm{M})$ in Krebs-Ringer buffer ( $\mathrm{pH} 7 \cdot 4$ ) consisting of $145 \mathrm{mM}$ $\mathrm{NaCl}, 5 \mathrm{mM} \mathrm{KCl}, 1.3 \mathrm{mM} \mathrm{MgCl}, 1.2 \mathrm{mM} \mathrm{NaH}_{2} \mathrm{PO}_{4}$, $1.3 \mathrm{mM} \mathrm{CaCl}_{2}, 10 \mathrm{mM}$ glucose and $20 \mathrm{mM}$ HEPES, at room temperature in the dark for $1 \mathrm{~h}$. Loaded cells were then washed free of extracellular dye, and the coverslip mounted in an open culture chamber placed on the stage of an inverted Nikon microscope and maintained at $37^{\circ} \mathrm{C}$ in Krebs-Ringer buffer. Dynamic video imaging was carried out as described previously (Morton et al. 1992), using Magical hardware and TARDIS software (Applied Images, Sunderland, UK) and a low light level intensified charge-coupled device camera (Photonic Science, Robertsbridge, UK). The TARDIS software creates dynamic pseudo-colour images of the cells, the colour scale representing the concentration of intracellular $\mathrm{Ca}^{2+}$, and therefore provides spatial and temporal resolution of the free $\mathrm{Ca}^{2+}$ concentration in individual cells.

\section{Results}

\section{PCR of $c D N A$ libraries}

Using a QUICK Screen universal human cDNA library as a template, the optimal PCR conditions permitting amplification of gene fragments from all five somatostatin receptor subtypes were determined (Fig. 1A). The identities of these fragments were subsequently confirmed by DNA sequencing (data not shown). Under identical conditions, we were able to amplify gene fragments of sst1 sst2, sst4 and sst5 receptors using the human heart cDNA library as a template (Fig. 1B). Each result was validated in three independent reactions. In marked contrast, the gene fragment of the sst3 receptor could not be amplified (Fig. 1B) in any of six independent PCR experiments. These data therefore suggested that mRNA for sst1, sst2, sst 4 and sst 5 - but not sst 3 - receptors are expressed in the human heart.

\section{RT-PCR of human heart tissue: chamber localisation}

RT-PCR on mRNA isolated from human right atrial appendage resulted in the amplification of sst1 sst2, sst4 and sst5 but not sst3 receptor gene fragments (Fig. 2A). This finding was consistent in biopsies taken from three
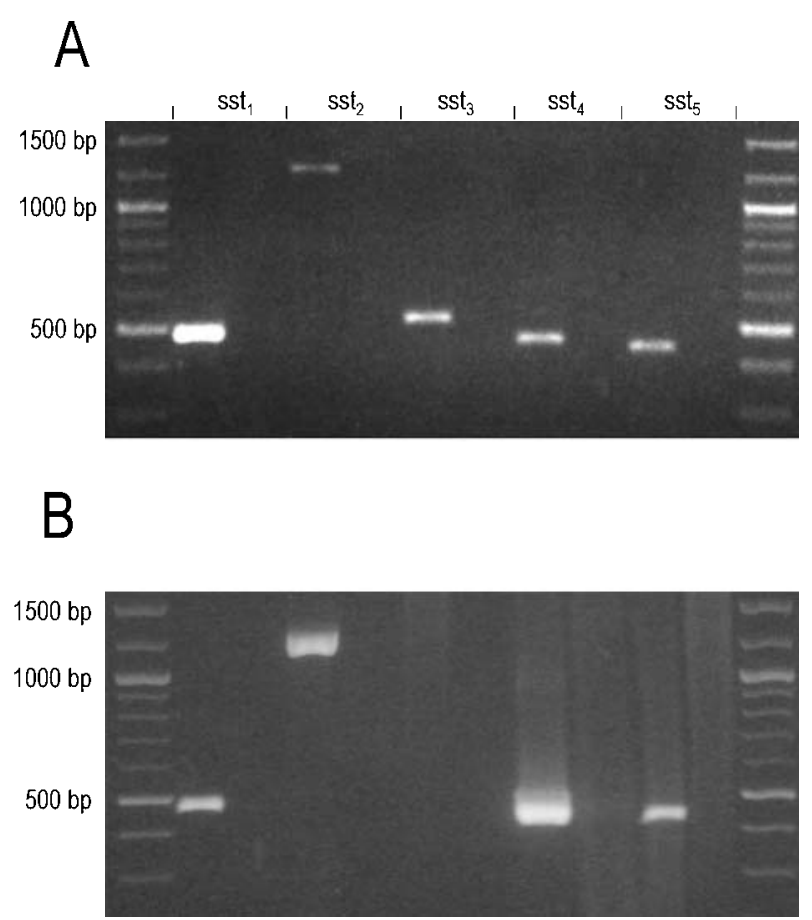

Figure 1 Agarose gel showing PCR products for each somatostatin receptor subtype obtained from the human universal cDNA library (A) and the human heart cDNA library (B). The outer lanes contain a $100 \mathrm{bp}$ DNA ladder. In the lane to the right of each product is loaded the product of a negative control reaction where water replaced the cDNA library. Expected PCR product sizes in base pairs: sst1, 481; sst2, 1241; sst3, 517; sst4, 455; sst5, 432.

different subjects with each experiment conducted in triplicate. Similarly mRNA encoding the same four somatostatin receptor subtypes was detected in tissue obtained from human left ventricular biopsies with the consistent absence of sst3 (Fig. 2B). Again, three separate biopsies, each taken from a different patient were studied in triplicate. These data are consistent with our earlier findings in the heart cDNA library and further suggest that mRNA for sst1, sst2, sst4 and sst5 - but not sst3 receptors are expressed throughout the human heart at the tissue level.

\section{RT-PCR of human cardiac fibroblasts}

Immunohistochemical studies of cultured human cardiac fibroblasts revealed that they stained positively for vimentin and for smooth muscle $\alpha$-actin (Fig. 3 ) but not for von-Willebrand factor. RT-PCR analysis of the messenger RNA extracted from these cultured cells produced amplification of the gene fragments for sst1, sst2, sst 4 and sst5 - but not sst 3 - receptors (Fig. 4A). These results were independent of cell passage number (one to five) and were consistent in all fibroblast lines established 


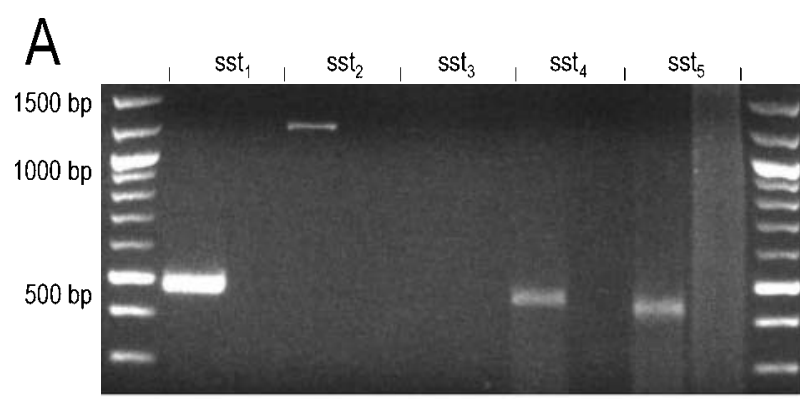

\section{B}

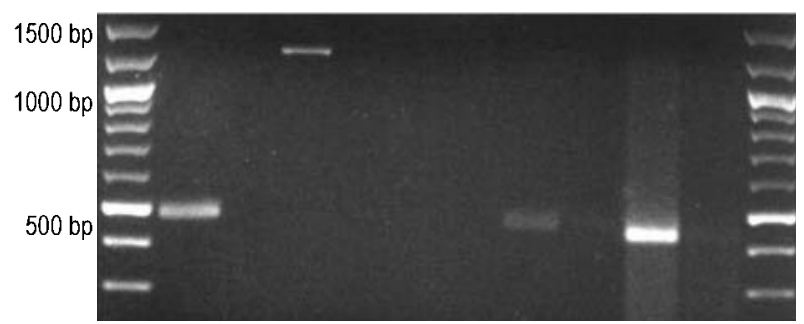

Figure 2 Agarose gel showing products of RT-PCR assays probing mRNA extracted from human right atrial appendage $(A)$ and human left ventricle (B) tissue for somatostatin receptor subtypes. The outer lanes contain a $100 \mathrm{bp}$ DNA ladder. In the lane to the right of each product is loaded the product of a negative control reaction where water replaced the reverse transcriptase enzyme in the reverse transcription reaction.

from three separate patients. They suggest that these four somatostatin receptor subtypes are expressed on human cardiac fibroblasts.

\section{RT-PCR of human cardiac myocytes}

RT-PCR analysis of the messenger RNA extracted from these cells produced amplification of the gene fragments for sst 1 and sst 2 receptors, but not for sst3, sst 4 and sst5 receptors (Fig. 4B). Due to the scarcity of isolated human cardiac myocytes (from donor hearts) only two subject samples were analysed ( $n=3$ experiments on each). Interestingly, however, these data suggest that only sst 1 and sst 2 receptors are expressed on human cardiac myocytes.

\section{Measurement of intracellular calcium mobilisation in human} cardiac fibroblasts

The addition of somatostatin $\left(10^{-6} \mathrm{M}\right)$ resulted in a rapid and significant mobilisation of intracellular calcium in cultured human cardiac fibroblasts (Fig. 5). This was consistent both early, after the first passage, and later, after the fifth passage ( $n=3$ patient samples). These data are consistent with the earlier RT-PCR data relating to expression of mRNA. They demonstrate that functional
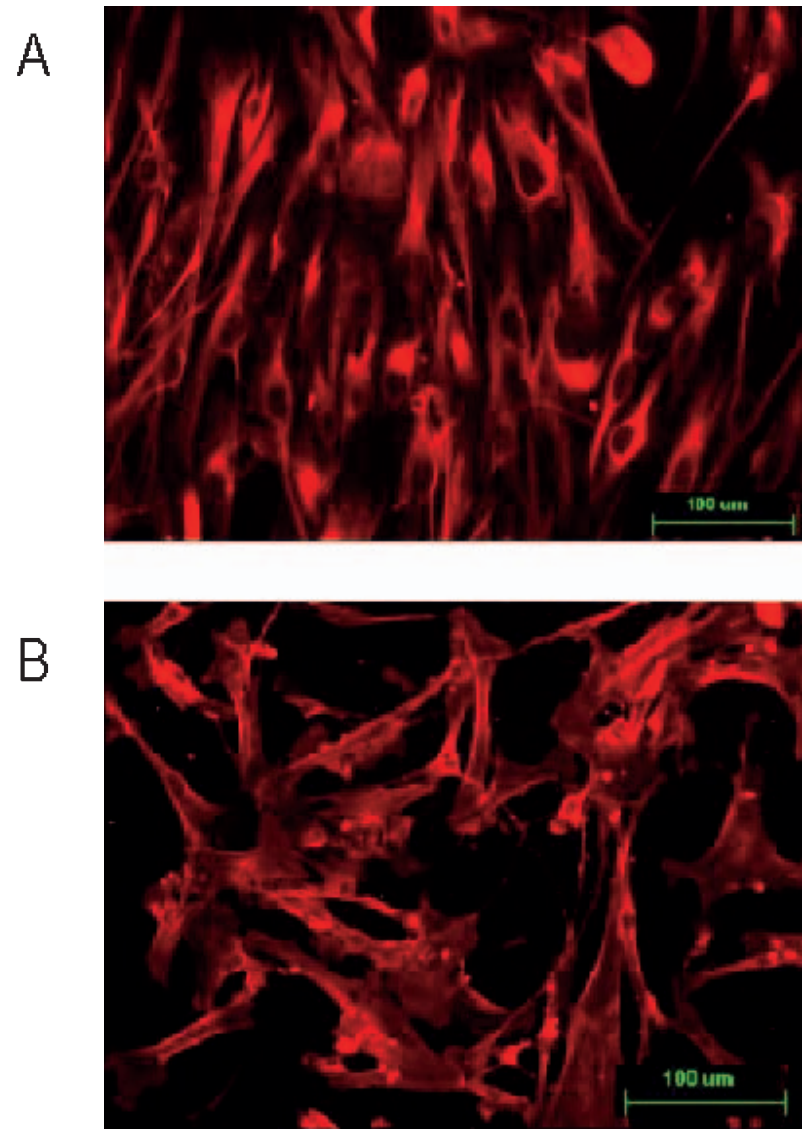

Figure 3 Immunohistochemical analysis of cultured human cardiac fibroblasts. Cells staining positively for vimentin (A) and smooth muscle $\alpha$ actin (B). Scale bar, $100 \mu \mathrm{m}$.

somatostatin receptors capable of coupling to intracellular messengers are expressed by human cardiac fibroblasts.

\section{Discussion}

PCR conditions were initially optimised using a human universal cDNA library, representing 13 different tissue cDNAs (including the heart). As anticipated, using such a broad tissue library we successfully established conditions to amplify gene fragments for all 5 somatostatin receptor subtypes. Next, using this approach we screened a human heart cDNA library and noted that the human heart expresses sst1, sst2, sst 4 and sst5 - but not sst 3 - receptors. Our subsequent data from RT-PCR analysis of myocardial biopsies are important in two ways. Firstly they are in keeping with our findings from the heart cDNA library thereby confirming that the mRNAs for the somatostatin receptor subtypes sst1, sst2, sst4 and sst5 are expressed in the human heart. This is important because the heart cDNA library was generated from 'whole heart' including 

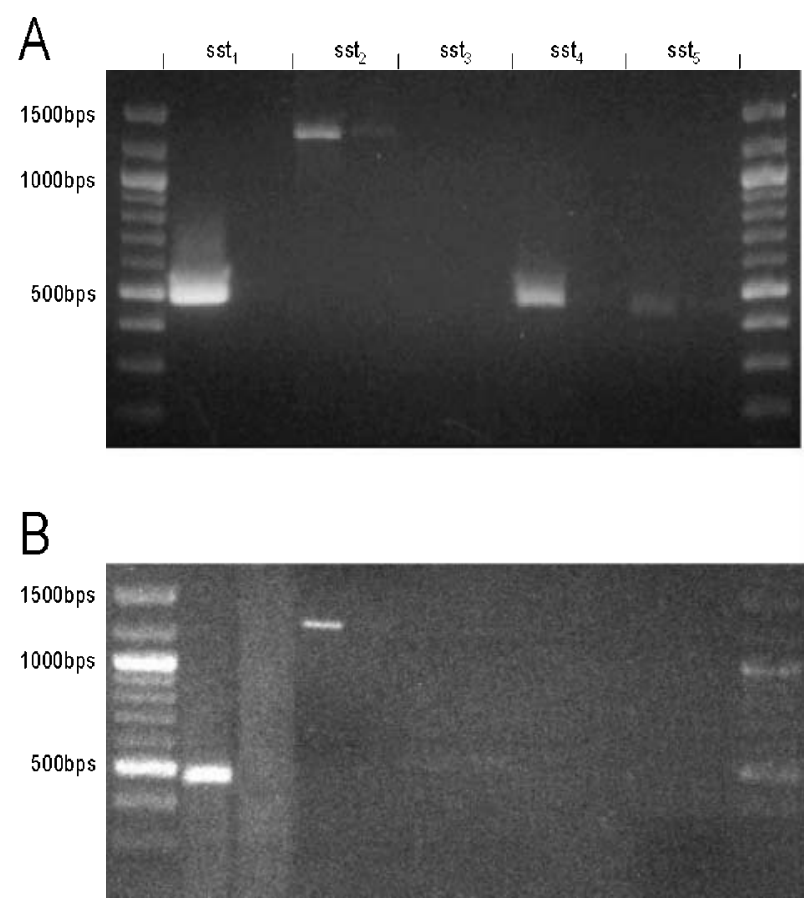

Figure 4 Agarose gel showing products of RT-PCR assays probing mRNA extracted from cultured human cardiac fibroblasts (A) and human cardiac myocytes (B) for somatostatin receptor subtype expression. The outer lanes contain a $100 \mathrm{bp}$ DNA ladder. In the lane to the right of each product is a negative control reaction as described in the legend of Fig. 2.

coronary arteries and possibly small amounts of the great vessels. In contrast, our biopsies were purely of myocardial origin and allow us to conclude that these receptors are specifically expressed by normal human myocardium. Second, the ubiquitous expression of sst1, sst2, sst 4 and sst 5 on both atrial and ventricular tissue, argues against any selectivity of function of somatostatin between atria and ventricle. It suggests that these receptors fulfil a more fundamental role in the myocardium throughout the human heart.

It is common for individual tissues to express more than one subtype of somatostatin receptor. The reasons why this occurs are not known but interactions between different receptor subtypes have been reported (Rocheville et al. 2000) and this may allow greater flexibility in the heart's response to somatostatin. One interesting difference between sst 3 and the other somatostatin receptors is its unique ability to couple to apoptosis (Sharma et al. 1996) rather than merely inhibiting growth. Its absence in the normal heart may indicate that it is desirable for somatostatin to modulate cell growth without causing cell death in this tissue. This study only analysed normal cardiac tissue and further studies will be required to determine whether this pattern of expression alters with disease.

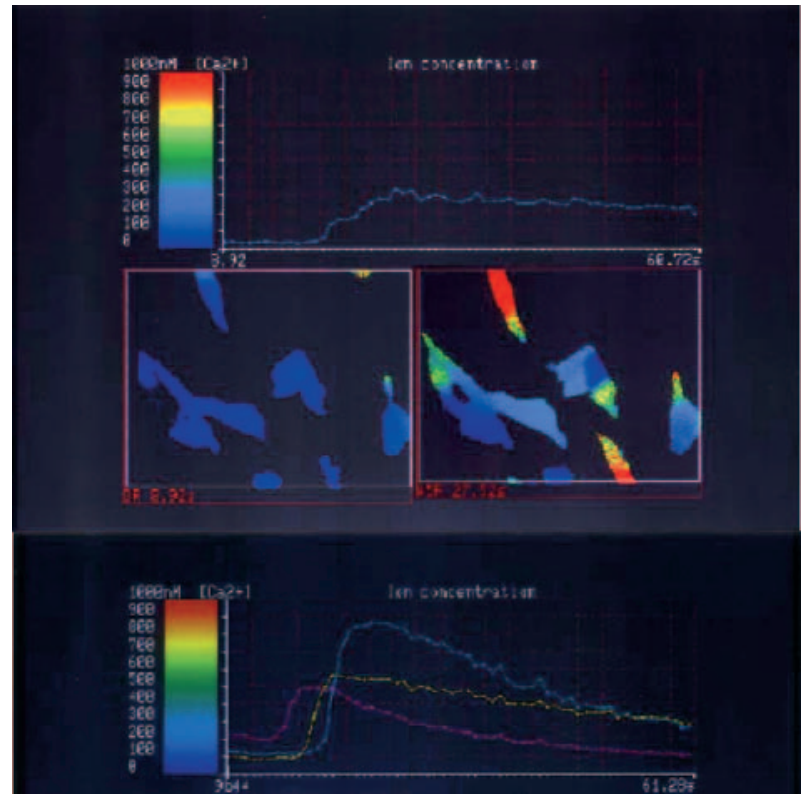

Figure 5 Calcium mobilisation in human cardiac fibroblasts before (left panel of cells) and after treatment with $10^{-6} \mathrm{M}$ somatostatin (right panel of cells). These pseudo-colour images correspond to the level of intracellular $\mathrm{Ca}^{2+}$. The treatment image represents the time of maximal response of these cells to somatostatin. Two time courses are illustrated. The upper trace illustrates the combined mobilisation of calcium by the field of cells. The lower trace illustrates the separate time courses of the individual cells.

At the cellular level cardiac myocytes and fibroblasts are the two main cellular components of the myocardium. Myocytes account for three-quarters of the heart's mass but are generally regarded as being terminally differentiated and unable to proliferate. Instead they can respond to appropriate stimuli by undergoing hypertrophy. In numerical terms, fibroblasts are the predominant cell type in the heart and proliferate readily in both health and disease states. They undergo major change in response to myocardial damage from ischaemia or infarction and during the development of LVH (Weber \& Brilla 1991). An important difference in receptor mRNA expression was identified at the cellular level with human cardiac fibroblasts expressing sst1, sst2, sst4 and sst5 receptors, while only sst 1 and sst 2 receptors are expressed by human cardiac myocytes. This is consistent with somatostatin mediating differing effects on the two major cell types in the heart. It also offers the potential to modulate human cardiac fibroblasts selectively through the sst 4 and sst 5 receptors without any effect on the myocyte population. The SRLs in common clinical use (octreotide and lanreotide) are active at both sst 2 and sst 5 receptors and would therefore be expected to mediate effects on both cell types.

Although we cannot exclude the possibility of cell culture influencing receptor mRNA expression, this is 
unlikely. In the case of myocytes, these cells were frozen immediately after isolation with little chance for gene expression to alter significantly.

Our fibroblasts were cultured for longer but receptor subtype expression did not change, at least qualitatively, during subsequent passages. Furthermore the same receptors were found on these cells as were present on whole myocardial tissue that was frozen immediately after removal from the patient.

An obvious limitation of PCR-based studies is that only gene transcription is detected which fails to provide information about whether the message is translated, in this case into functional receptors on the cell surface. Consequently, we sought to demonstrate the expression of somatostatin receptors on human cardiac fibroblasts. Mobilisation of intracellular calcium was performed as this response can be resolved at the level of a single cell and has been identified to varying degrees by all subtypes of recombinant somatostatin receptors expressed in COS-7 cells (Akbar et al. 1994, Tomura et al. 1994). Using this approach, human cardiac fibroblasts were shown to mobilise intracellular calcium in response to somatostatin, proving that functional somatostatin receptors are expressed on the cell surface. The lack of commercially available receptor subtype selective agonists and antagonists at the time of study hampered further clarification of the pharmacology and, hence, functional subtypes expressed.

This study provides the platform for further experiments to firmly establish a link between somatostatin receptors and cardiac growth. It shows that the mRNAs for somatostatin receptor subtypes sst1, sst2, sst 4 and sst5 are expressed by the human heart. At the tissue level there is uniform expression between atrial and ventricular tissue but at the cellular level there is differential expression with sst1 and sst2 being expressed in both human cardiac myocytes and fibroblasts but sst 4 and sst 5 only being found in human cardiac fibroblasts. At least one subtype of these receptors couples functionally to the moblisation of intracellular calcium in human cardiac fibroblasts. These findings would be consistent with the notion that in the treatment of acromegaly with somatostatin analogues, there could be a direct effect on the heart causing LVH regression, in addition to effects due to lowering IGF-I. Such a direct effect might be beneficial in other conditions where the presence of LVH confers risk. This is consistent with a case report (Gunal et al. 1996) and a small Japanese study (Demirtas et al. 1998) documenting regression of LVH due to hypertrophic cardiomyopathy with octreotide treatment. An implication relevant to modern management of acromegaly is that treatment with the growth hormone receptor antagonist pegvisomant (Fuh et al. 1992) would be expected to reduce circulating and local IGF-I levels in the heart but would not activate local somatostatin receptors. It remains to be seen whether the encouraging results of treatment in terms of biochemical and symptom control (Trainer et al. 2000, van der Lely et al. 2001) are mirrored in equally beneficial effects on LVH regression and, in turn, cardiovascular morbidity and mortality.

\section{Acknowledgements}

We acknowledge the expert technical help of Mr Phil Warburton in performing assays measuring mobilisation of calcium in cardiac fibroblasts. We are grateful to Professor Magdi Yacoub, Dr Sian Harding and the Royal Brompton and Harefield NHS Trust Transplant program for donor human hearts used to isolate human cardiac myocytes. We are also grateful to Dr Mark Gurnell for helpful comments on this manuscript.

\section{Funding}

Funding was provided by a British Heart Foundation Junior Research Fellowship to William Smith. Dawn Adamson was also supported by a British Heart Foundation Junior Research Fellowship and Mark Kearney is a British Heart Foundation Intermediate Research Fellow. Stephen Ball is the recipient of a British Heart Foundation Professorship and Tony Balmforth was supported by a British Heart Foundation Basic Science Senior Lectureship. The authors declare that there is no conflict of interest that would prejudice the impartiality of this scientific work.

\section{References}

Akbar M, Okajima F, Tomura H, Majid M A, Yamada Y, Seino S \& Kondo Y 1994 Phospholipase $\mathrm{C}$ activation and $\mathrm{Ca}^{2+}$ mobilization by cloned human somatostatin receptor subtypes $1-5$, in transfected COS-7 cells. FEBS Letters 348 192-196.

Baldelli R, Ferretti E, Jaffrain-Rea M L, Iacobellis G, Minniti G, Caracciolo B, Moroni C, Cassone R, Gulino A \& Tamburrano G 1999 Cardiac effects of slow-release lanreotide, a slow-release somatostatin analog, in acromegalic patients. Journal of Clinical Endocrinology and Metabolism 84 527-532.

Bruno JF, Xu Y, Song J \& Berelowitz M 1993 Tissue distribution of somatostatin receptor subtype messenger ribonucleic acid in the rat. Endocrinology 133 2561-2567.

Buscail L, Esteve J P, Saint-Laurent N, Bertrand V, Reisine T, O'Carroll, AM, Bell G I, Schally A V, Vaysse N \& Susini C 1995 Inhibition of cell proliferation by the somatostatin analogue RC-160 is mediated by somatostatin receptor subtypes SSTR2 and SSTR 5 through different mechanisms. PNAS 92 1580-1584.

Chanson P, Timsit J, Masquet C, Warnet A, Guillausseau P J, Birman P, Harris A G \& Lubetzki J 1990 Cardiovascular effects of the somatostatin analog octreotide in acromegaly. Annals of Internal Medicine 113 921-925.

Clayton RN 2003 Cardiovascular function in acromegaly. Endocrine Reviews 24 272-277.

Colao A, Cuocolo A, Marzullo P, Nicolai E, Ferone D, Florimonte L, Salvatore M \& Lombardi G 1999 Effects of 1-year treatment with octreotide on cardiac performance in patients with acromegaly. Journal of Clinical Endocrinology and Metabolism 84 17-23.

Colao A, Baldelli R, Marzullo P, Ferretti E, Ferone D, Gargiulo P, Petretta M, Tamburrano G, Lombardi G \& Liuzzi A 2000 a Systemic hypertension and impaired glucose tolerance are 
independently correlated to the severity of the acromegalic cardiomyopathy. Journal of Clinical Endocrinology and Metabolism $\mathbf{8 5}$ 193-199.

Colao A, Marzullo P, Ferone D, Spinelli L, Cuocolo A, Bonaduce D, Salvatore M, Boerlin V, Lancranjan I \& Lombardi G 2000 b Cardiovascular effects of depot long-acting somatostatin analog Sandostatin LAR in acromegaly. Journal of Clinical Endocrinology and Metabolism 85 3132-3140.

Colao A, Marzullo P, Di Somma C \& Lombardi G 2001a Growth hormone and the heart. Clinical Endocrinology 54 137-154.

Colao A, Cuocolo A, Marzullo P, Nicolai E, Ferone D, Della Morte AM, Pivonello R, Salvatore M \& Lombardi G $2001 b$ Is the acromegalic cardiomyopathy reversible? Effect of 5-year normalization of growth hormone and insulin-like growth factor I levels on cardiac performance. Journal of Clinical Endocrinology and Metabolism 86 1551-1557,

Davies CH, Davia K, Bennett JG, Pepper JR, Poole-Wilson PA \& Harding SE 1995 Reduced contraction and altered frequency response of isolated ventricular myocytes from patients with heart failure. Circulation 92 2540-2549.

Delafontaine P 1995 Insulin-like growth factor I and its binding proteins in the cardiovascular system. Cardiovascular Research $\mathbf{3 0}$ $825-834$.

Demirtas E, Sag C, Kursaklioglu H, Uzun M, Uzbay T, Tore HF, Kose S, Genc C \& Demirkan D 1998 Effects of octreotide in patients with hypertrophic obstructive cardiomyopathy. Japanese Heart Journal 39 173-181.

Ezzat S, Snyder PJ, Young WF, Boyajy LD, Newman C, Klibanski A, Molitch ME, Boyd AE, Sheeler L \& Cook DM 1992 Octreotide treatment of acromegaly. A randomized, multicenter study. Annals of Internal Medicine 117 711-718.

Frustaci A, Chimenti C, Setoguchi M, Guerra S, Corsello S, Crea F, Leri A, Kajstura J, Anversa P \& Maseri A 1999 Cell death in acromegalic cardiomyopathy. Circulation 99 1426-1434.

Fuh G, Cunningham BC, Fukunaga R, Nagata S, Goeddel DV \& Wells JA 1992 Rational design of potent antagonists to the human growth hormone receptor. Science 256 1677-1680.

Gunal AI, Isik A, Celiker H, Eren O, Celebi H, Gunal S Y \& Luleci C 1996 Short term reduction of left ventricular mass in primary hypertrophic cardiomyopathy by octreotide injections. Heart $\mathbf{7 6}$ 418-421.

Holdaway IM, Rajasoorya RC \& Gamble GD 2004 Factors influencing mortality in acromegaly. Journal of Clinical Endocrinology and Metabolism 89 667-674.

Levy D, Salomon M, D'Agostino RB, Belanger AJ \& Kannel WB 1994 Prognostic implications of baseline electrocardiographic features and their serial changes in subjects with left ventricular hypertrophy. Circulation 90 1786-1793.

Lie JT 1980 Pathology of the heart in acromegaly: anatomic findings in 27 autopsied patients. American Heart Journal 100 41-52.

Lim MJ, Barkan AL \& Buda AJ 1992 Rapid reduction of left ventricular hypertrophy in acromegaly after suppression of growth hormone hypersecretion. Annals of Internal Medicine 117 719-726.

Manelli F, Desenzani P, Boni E, Bugari G, Negrini F, Romanelli G, Grassi V \& Giustina A 1999 Cardiovascular effects of a single slow release lanreotide injection in patients with acromegaly and left ventricular hypertrophy. Pituitary 2 205-210.

Mathew J, Sleight P, Lonn E, Johnstone D, Pogue J, Yi Q, Bosch J, Sussex B, Probstfield J, Yusuf S \& Heart Outcomes Prevention Evaluation H 2001 Reduction of cardiovascular risk by regression of electrocardiographic markers of left ventricular hypertrophy by the angiotensin-converting enzyme inhibitor ramipril. Circulation 104 1615-1621.

Merola B, Cittadini A, Colao A, Ferone D, Fazio S, Sabatini D, Biondi, B, Sacca L \& Lombardi G 1993 Chronic treatment with the somatostatin analog octreotide improves cardiac abnormalities in acromegaly. Journal of Clinical Endocrinology and Metabolism 77 790-793.
Morton AJ, Hammond C, Mason WT \& Henderson G 1992 Characterisation of the L- and N-type calcium channels in differentiated SH-SY5Y neuroblastoma cells: calcium imaging and single channel recording. Brain Research Molecular Brain Research 13 53-61.

Neuss M, Regitz-Zagrosek V, Hildebrandt A \& Fleck E 1996 Isolation and characterisation of human cardiac fibroblasts from explanted adult hearts. Cell and Tissue Research 286 145-153.

O'Carroll AM, Raynor K, Lolait SJ \& Reisine T 1994 Characterization of cloned human somatostatin receptor SSTR 5. Molecular Pharmacology 46 291-298.

Orme SM, McNally RJ, Cartwright RA \& Belchetz PE 1998 Mortality and cancer incidence in acromegaly: a retrospective cohort study. United Kingdom Acromegaly Study Group. Journal of Clinical Endocrinology and Metabolism 83 2730-2734.

Padayatty SJ, Perrins EJ \& Belchetz PE 1996 Octreotide treatment increases exercise capacity in patients with acromegaly. European Journal of Endocrinology 134 554-559.

Patel YC, Greenwood MT, Warszynska A, Panetta R \& Srikant CB 1994 All five cloned human somatostatin receptors (HSSTR1-5) are functionally coupled to adenylyl cyclase. Biochemical and Biophysical Research Communications 198 605-612.

Rocheville M, Lange DC, Kumar U, Sasi R, Patel RC \& Patel YC 2000 Subtypes of the somatostatin receptor assemble as functional homo- and heterodimers. Journal of Biological Chemistry 275 $7862-7869$.

Sharma K, Patel YC \& Srikant CB 1996 Subtype-selective induction of wild-type P53 and apoptosis, but not cell cycle arrest, by human somatostatin receptor 3. Molecular Endocrinology 10 1688-1696.

Thuesen L, Christensen SE, Weeke J, Orskov H \& Henningsen P 1989 The cardiovascular effects of octreotide treatment in acromegaly: an echocardiographic study. Clinical Endocrinology 30 619-625.

Tokgozoglu SL, Erbas T, Aytemir K, Akalin S, Kes S \& Oram E 1994 Effects of octreotide on left ventricular mass in acromegaly. American Journal of Cardiology 74 1072-1074.

Tomura H, Okajima F, Akbar M, Abdul MM, Sho K \& Kondo Y 1994 Transfected human somatostatin receptor type 2, SSTR2, not only inhibits adenylate cyclase but also stimulates phospholipase C and $\mathrm{Ca}^{2+}$ mobilization. Biochemical and Biophysical Research Communications 200 986-992.

Trainer PJ, Drake WM, Katznelson L, Freda PU, Herman-Bonert V, van der Lely AJ, Dimaraki EV, Stewart PM, Friend KE, Vance ML, Besser GM, Scarlett JA, Thorner MO, Parkinson C, Klibanski A, Powell JS, Barkan AL, Sheppard MC, Malsonado M, Rose DR, Clemmons DR, Johannsson G, Bengtsson BA, Stavrou S, Kleinberg DL, Cook DM, Phillips LS, Bidlingmaier M, Strasburger CJ, Hackett S, Zib K, Bennett WF \& Davis RJ 2000 Treatment of acromegaly with the growth hormone-receptor antagonist pegvisomant. New England Journal of Medicine 342 1171-1177.

van der Lely AJ, Hutson RK, Trainer PJ, Besser GM, Barkan AL, Katznelson L, Klibanski A, Herman-Bonert V, Melmed S, Vance ML, Freda PU, Stewart PM, Friend KE, Clemmons DR, Johannsson G, Stavrou S, Cook DM, Phillips LS, Strasburger CJ, Hackett S, Zib KA, Davis RJ, Scarlett JA \& Thorner MO 2001 Long-term treatment of acromegaly with pegvisomant, a growth hormone receptor antagonist. Lancet 358 1754-1759.

Verdecchia P, Schillaci G, Borgioni C, Ciucci A, Gattobigio R, Zampi I, Reboldi G \& Porcellati C 1998 Prognostic significance of serial changes in left ventricular mass in essential hypertension. Circulation 97 48-54.

Weber KT \& Brilla CG 1991 Pathological hypertrophy and cardiac interstitium. Fibrosis and renin-angiotensin-aldosterone system. Circulation 83 1849-1865.

Wright AD, Hill DM, Lowy C \& Fraser TR 1970 Mortality in acromegaly. Quarterly Journal of Medicine 39 1-16.

Received 16 August 2005

Accepted 13 September 2005 